\section{POSTMORTEM COMPUTED TOMOGRAPHY OF THE SKULL FOR HUMAN IDENTIFICATION BASED ON THE MORPHOLOGY OF FRONTAL SINUSES}

\author{
Carvalho Y.M. ${ }^{1}$, Jacometti V.2, Franco A.3, Da Silva R. H. A.1,2, Silva R. F.4,5
}

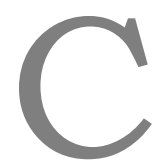

omputed tomography (CT) became an important tool in the armamentarium of Forensic Radiology. Over the last decade, postmortem imaging was broadly used in the search for the cause of death and in human identification. In the latter, frontal sinuses have been increasingly used because of its distinctive and highly immutable morphology. The present study reports a case of human identification through the comparison between antemortem (AM) and postmortem (PM) axial CT images of the frontal sinuses. An adult male victim was referred for human identification with a set of 23 images of the frontal sinuses in axial view. PMCT was performed to reproduce and compare the AM data. Positive identification was achieved based on the analysis of area, shape, septa and lobes of the frontal sinuses. Based on the case report, it can be concluded that Forensic Radiology represents an important branch within the forensic sciences. Forensic experts must be aware of this tool in order to reach optimal outcomes in human identification - especially those founded on the comparison of frontal sinuses.

Keywords: frontal sinus, computed tomography, forensic dentistry, radiology.

Corresponding author: Da Silva R.H.A., e-mail: ricardohenrique@usp.br

For citation: Carvalho Y.M., Jacometti V., Franco A., Da Silva R.H.A., Silva R.F. Postmortem computed tomography of the skull for human identification based on the morphology of frontal sinuses. REJR 2019; 9(4):170-176. DOI:10.21569/2222-7415-2019-9-4-170-176.

Статья получена: $\quad 27.08 .19 \quad$ Статья принята: 28.10 .19
1 - Forensic Dentistry Specialization Course, School of Dentistry of Ribeirão Preto, University of São Paulo.

Ribeirão Preto, Brazil.

2 - Department of Pathology and Legal Medicine, Ribeirão Preto Medical

School, University of São Paulo.

Ribeirão Preto, Brazil. 3 - Area of Oral Imaging, Faculdade São Leopoldo Mandic, Instituto de Pesquisas São Leopoldo Mandic.

Campinas, Brasil.

4 - Department of Dentistry - Forensic Dentistry, Federal University of Goiás. Goiânia, Brazil.

5 - Department of Forensic Odontology and Anthropology, Scientific Police of Goiás. Goiânia, Brazil.

1 - Отдем специализированной судебномедицинской стоматомогии, Шкома стоматомогии Рибейран-Прету, Университет СанПаулу.

Рибейран-Прету, Бразимия.

\section{ПРИМЕНЕНИЕ ПОСМЕРТНОЙ КОМПЬЮТЕРНОЙ ТОМОГРАФИИ ЧЕРЕПА С ЦЕ- АЬЮ ИАЕНТИФИКАЦИИ ЧЕАОВЕКА НА ОСНОВАНИИ МОРФОЛОГИИ АОБНЫХ СИНУСОВ}

\author{
Карвальхо Ю.М. ' , Якометти В.2, Франко А. ${ }^{3}$, \\ $\triangle$ А Си^ва Р. Х. А. ${ }^{1,2}$, Си^ва Р.Ф.4,5
}

омпьютерная томография (КТ) стала важным инструментом в арсенале рентгенолога в судебно-медицинской практике. За последнее десятилетие по1 смертная визуализация широко использовалась дмя поиска причины смерти и
идентификации мюдей. В рамках идентификации все чаще используются мобные синусы из-за их отличительной и неизменной морфологии. В настоящем исследовании описан случай идентификации человека путем сравнения аксиальных КТ-изображений мобных синусов до смерти и посмертно. Взрослый мужчина-жертва был направлен дмя идентификации с 23 изображениями мобных синусов в аксиальной реконструкции. Посмертная КТ была выполнена для воспроизведения и сравнения данных до смерти. Поможительная идентификация была достигнута на основе анализа площади, формы, перегородок и долей мобных синусов. На основании данного кАинического случая можно сделать вывод, что судебная рентгенология представляет собой важную отрасль судебной медицины. Эксперты-криминалисты должны знать об этом методе, чтобы достичь оптимальных результатов при идентификации мюдей, особенно тех, которые основаны на сравнении мобных синусов.
2 - Кафедра патологии и юридической медицины, Медицинская школа Рибейран-Прету, Университет СанПаулу. Рибейран-Прету, Бразикия.

3 - Отделение визуализации полости рта, Сан-

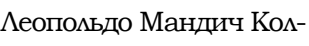
медж, СанМанди НИИ.

Кампинас, Бразилия. 4 - Кафедра стоматологии - судебная стоматомогия, Федеральньй университет Гояс. Гояния, Бразилия. 5 - Отдем судебной стоматологии и антропологии, Научная помиция Гояса. Гояния, Бразимия. 
КАючевые слова: мобные синусы, компьютерная томография, судебная стоматомогия, рентгеномогия.

Контактный автор: Да Симьва Р. Х. A., e-mail: ricardohenrique@usp.br

Для иитирования: Карвальхо Ю.М., Якометти В., Франко А., Да Силва Р. Х. А., Силва Р.Ф. Применение посмертной компьютерной томографии черепа с иелью идентификаиии человека на основании морфологии лобных синусов. REJR 2019; 9(4):170-176. DOI:10.21569/2222-7415-2019-9-4-170-176.
Received:
27.08.19
Accepted:
28.10.19

\section{I}

\section{ntroduction.}

Human identification is performed in a compariteve basis between antemortem (AM) and postmortem (PM) data [1]. In particular, distinctive material found AM is tested for matching with PM records and vice versa [1]. Distinctiveness can detected in therapeutic, morphologic and pathologic evidences [2]. More importantly, the combination of distinctive evidences within a victim will dictate the prognosis of human identification into positive identification, possible identification or exclusion [3]. Cases lacking evidence will be categorized as insufficient and will not enable human identification [3].

Forensic Radiology bridges an important gap in medico-legal autopsies by enabling the search for distinctive skeletal features that might contribute to human identification [3, 4]. Dentomaxillofacial imaging has an evident relevance when it comes to human identification because it allows the visualization of several dental and skeletal structures simultaneously [5]. PM computed tomography (CT) is an advanced tool in the forensic sciences [6]. Currently, this tool is combined with other PM image techniques broadly used for the investigation of the cause of death and human identification in virtual-autopsy-like forensic procedures [7-10].

PM radiographs and $\mathrm{CT}$ scans of the frontal sinuses have been added to comparative human identifications reported in the scientific literature [11-15]. In practice, they increase the quantity and quality of evidences. Specifically, the morphology of the frontal sinuses is considered very distinctive between persons [16] - especially when sinuses' volume and area are calculated and the amount, position and agulation of lobes and septa are analyzed. All these features can be reliably assessed through PMCT and the combination of them may result in an important evidence to be used and compared with AM data in human identifications.

This study aimed to report a case of positive human identification established by the comparison between AM and PMCT images of the frontal sinuses.

\section{Case report.}

An unknown cadaver found in advanced decomposition and under water was referred to human identification at the local forensic unit. Human identification pointed towards an adult male. Inspection of the dentomaxillofacial region revealed metal plates and screws used for surgical fixation of bones around the left orbit. The fixation appliances did not have their respective serial numbers.

Police investigations were carried out among relatives of the potential victims (from a missing persons list). The relatives of the alleged victim were requested to provide any medical or dental radiographs, or photographic material from social media. Twenty-three axial slices of CT scans of the skull were provided as AM evidence. Twelve slices revealed bilateral frontal sinuses with inherent septa (Fig. 1). The CT images were obtained in a multi-slice CT device with window setting type for brain visualization.

In order to establish comparable PM data, the frontal bone was removed from the skull (because the cadaver was in advanced stage of decomposition) using an electric saw and underwent CT scanning. The PMCT images were imported into Osirix ${ }^{\circledR}$ (Pixmeo SARL, Geneva, Switzerland) software package with simulated window for brain. Using sofware navigation tools, the PM images were rotated to reach the same position of the AM images. This procedure enabled a qualitative morphological comparison between frontal sinuses.

AM/PM comparison aiming reconciliation was performed using Adobe Photoshop CC ${ }^{\circledR}$ (Adobe Systems, San Jose, EUA). The area of the sinuses in axial view were selected AM and transposed to PM with opacity levels set in $50 \%$. The comparison was performed in multiple slices to guarantee more reliability to the process. AM/PM compatibility of sinuses' shape and size was detected in every comparison as well as the number of lobes and septa (Fig. 2). The comparison of frontal sinuses contributed to a positive human 


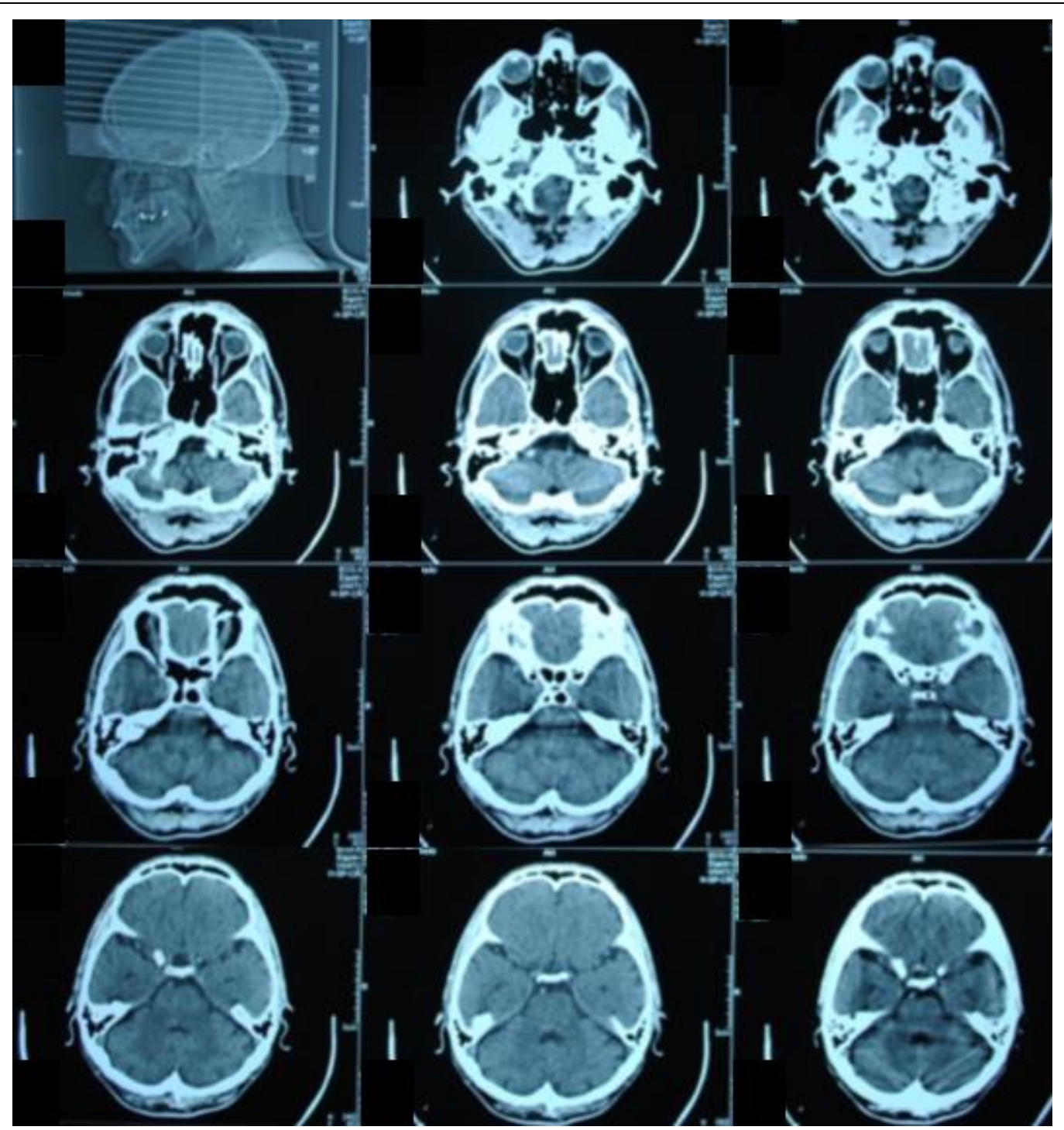

Fig. 1 (Рис. 1)

\section{Fig. 1. MSCT.}

Antemortem computed tomography scans showing maxillofacial structures and the frontal sinuses in axial view. Eleven slices are provided covering the frontal sinuses from their inferior to superior anatomic limits. The sinuses are depicted as hypodense areas in the anterior region of the skull - more specifically into the frontal bone.

\section{Рис. 1. МСКт.}

При компьютерной томографии до смерти определяются челюстно-лицевые структуры и аксиальной плоскости. Представлено одиннадцать срезов, охватывающих мобные синусы от их нижних до верхних анатомических границ. Синусы явцяются гиподенсными областями в передней области черепа, бомее конкретно, в цобной кости.

identification.

\section{Discussion.}

Forensic Radiology is an important tool for human identification. However, it becomes even more essential in complex cases, such as those that involve charred, decomposed, mutilated and skeletonized victims. The case reported in this study showed a victim that was found under water in advanced decomposition. In these victims soft tissue is progressively destroyed and fingerprints are often missing. Consequently, imagi- nological information from hard tissue, such as the bone outline of frontal sinuses, can be of utmost importance for human identification.

The scientific literature describes several techniques for the assessment and analysis of the frontal sinuses [17-20]. In short, the techniques may be qualitative and quantitative. The first are usually founded on AM/PM superimposition of sinuses, while the second relies in the number of lobes, septa and size of the frontal sinuses as well as the distance between sinuses and adjacent 

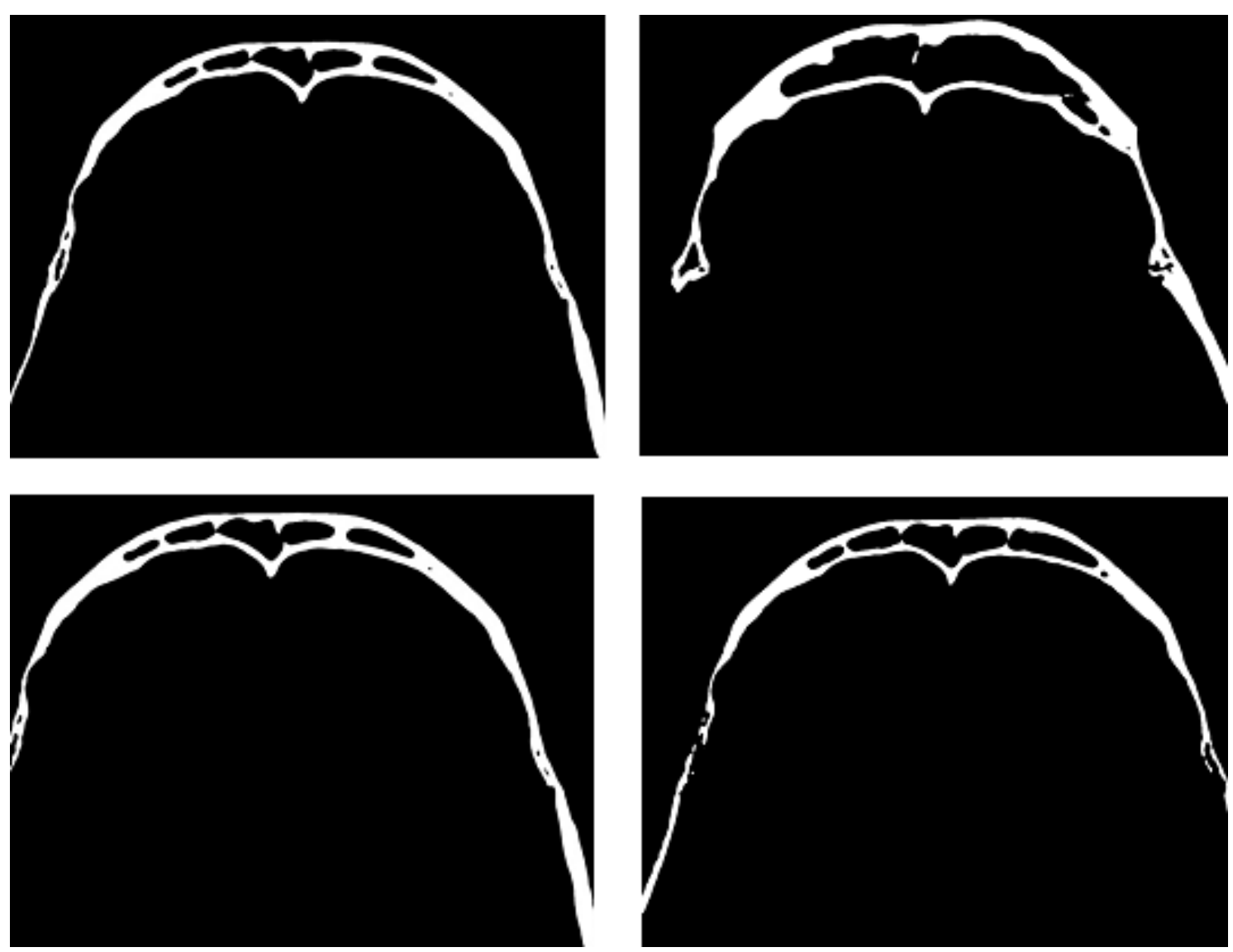

Fig. 2 (Рис. 2)

\section{Fig. 2. MSCT.}

Postmortem computed tomography scans showing the frontal sinuses in axial view. The sinuses are bilaterally present and visible. Hyperdense areas within the sinuses represent bone septa that divide the sinuses into lobes. The median septum is laterally displaced revealing a distinctive morphological feature to be considered for human identification purposes.

\section{Рис. 2. МСКт.}

При посмертной компьютерной томографии определяются цобные синусы в аксиальной плоскости. Синусы визуализируются с двух сторон. Гиперденсные структуры внутри синусов представляют собой костные перегородки, которые делят синусы на доли. Срединная перегородка смещена матерально, что является отличительным морфологическим признаком, который следует учитывать при идентификации человека.

bone structures [17]. An example of the techniques applied nowadays is the approach developed by Talitsumak et al. [21], which considers as identifying parameters the presence or absence of sinuses, septa and lobes. This technique was established in three-dimensional reconstructions of CT scans. However, recent studies reproduced it in comparisons between AM/PM anteroposterior radiographs and $\mathrm{AM} / \mathrm{PM}$ lateral cephalometric radiographs [22-24]. In the present study, the qualitative approach was used because measurements would be hampered by eventual differences in the CT scanning angle AM and PM. In other words, the AM data was obtained with standard CT image acquisition protocols, while the PM data was obtained arbritarily positioning the frontal bone (without soft tissue) in a CT machine. Is this con- text, the qualitative approach suited better to the circumstances.

The human identification process must be supported by the convergence of distinctive features found AM and PM [25, 26]. In this study, the frontal sinuses were bilaterally visible, asymmetrical, with on lobe in each side and a central fused lobe. The combination of these features increased the distinctiveness of the victim's sinuses, which became useful for human identification due to the convergence between AM and PMCT images (Fig. 3). Clearly, slightly discrepant morphological details were visible after superimposition. The rationale behind the differences relies on the different equipment, scanning positioning and image acquisition seetings between AM and PM data collection. Despite the differences, the bone outline of 

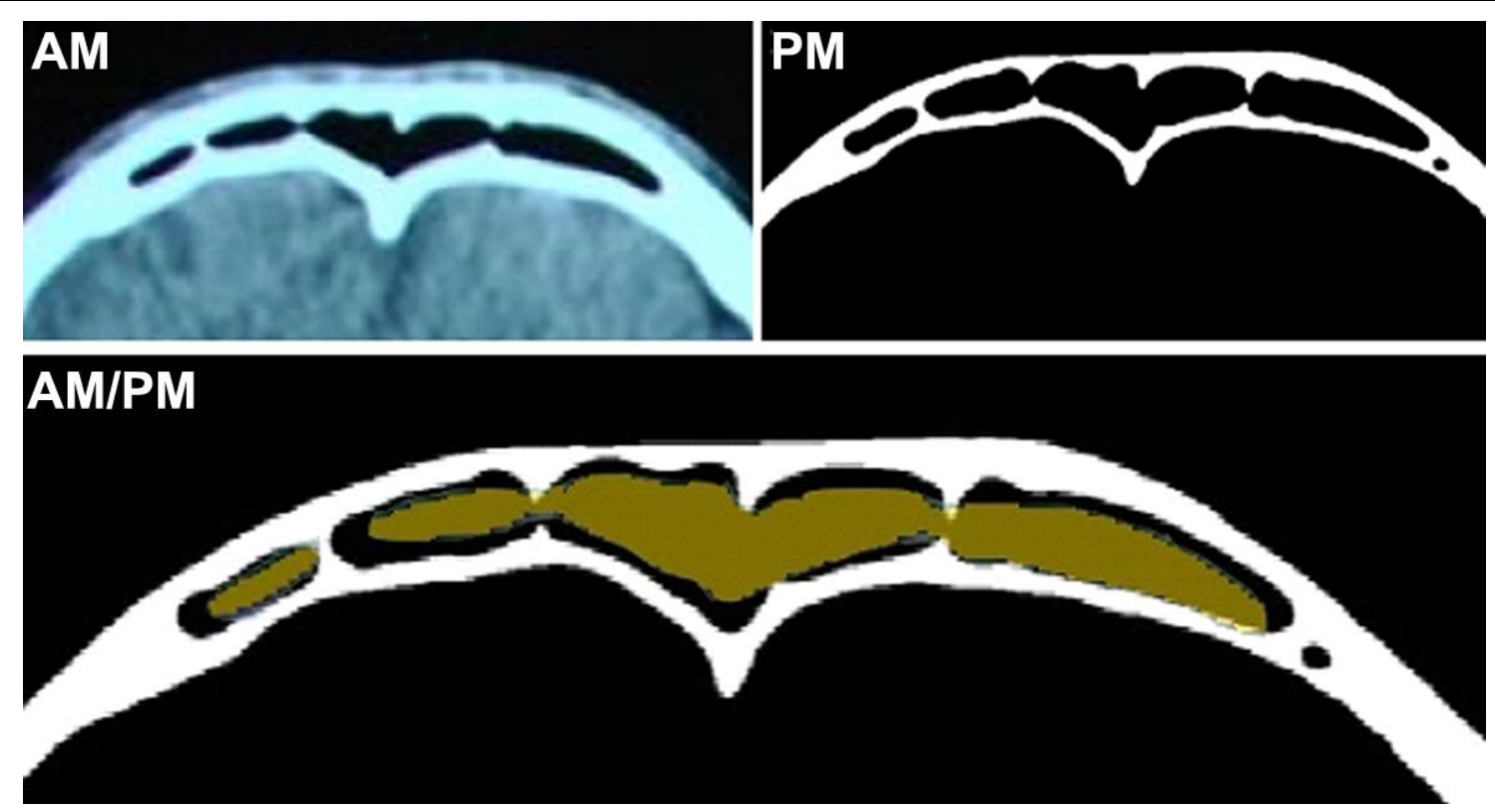

Fig. 3 (Рис. 3)

\section{Fig. 3. MSCT.}

Comparison between antemortem (AM) and postmortem (PM) computed tomography scans of the frontal sinuses showing compatibility in the number, distribution and morphology of the frontal sinuses, lobes and septa. Reconciliation images (AM/PM) are provided through the superimposition of hyperdense bone outline (PM) and the hypodense area of the (true) frontal sinuses (AM). Dark brown color was used to highlight the shape of the sinus space observed AM into the frontal bone space observed PM.

\section{Рис. 3. МСКт.}

Сравнение КТ изображений мобных синусов, проведенных до (АМ) и после (РМ) смерти, показывающих совместимость по количеству, распределению и морфологии мобных синусов, а также долей и перегородок. Синхронизация изображений (АМ/РМ) обеспечивается наложением гиперденсного контура кости (РМ) на гиподенсную область (истинных) цобных синусов (АМ). Темно-коричневый цвет был использован дмя выделения формы пространства синуса до смерти в пространстве мобной кости после смерти.

the frontal sinuses was preserved and available for a reliable comparison and reconciliation.

The contributions of PMCT for human identification in the forensic practice is clearly not restricted to the analysis of frontal sinuses or other anatomic structures hardly visualized in medical autopsies. Detailed investigations can be established in order to build an anthropological profile of the victim [27, 28]; forensic facial reconstruction can be performed [29]; firearm projectiles can be tracked prior to traditional autopsies [30]; and the data can be continuously analyzed in a digital environment over the time without the need for exhumations.

Despite the several contributions of PMCT to forensic sciences, it is important to note that limitations may arise. Knowledge of the interface between forensic medicine/anthropology/dentistry and radiology is essential to enable reliable image analysis dedicated to human identification. Additionally, high-tech imaging with proper devices and facilities may represent an expensive approach to specific morgues and forensic services. Finally, PM forensic imaging becomes limited when AM data is missing. This limitation rises a flag of attention to bring awareness to health science professionals for producing and properly storing imaginological records in the routine of medical services. Concommitantly, victims' relatives should keep and provide any AM material when requested by Law.

Preferably, a quantitative analysis of the frontal sinuses should be established (when feasible) for optimal performances in practice. In the present case, the only AM evidence was a printed set up of CT slices provided by the relatives. Hence, advanced image analyses were hampered and a detailed quantitative assessment was limited. However, the bidimensional qualitative analysis performed through the sumperimposition of $\mathrm{AM} / \mathrm{PM}$ images of the frontal sinuses was feasible and contributed to the identification process.

Future human identification cases should be reported in the scientific literature to highlight the importance of PMCT for the analysis and comparison of frontal sinuses in the forensic sciences and to enabe a discussion of protocols and techniques applied in the field. Original studies are 


\section{RUSSIAN ELECTRONIC JOURNAL OF RADIOLOGY}

also encouraged to support human identification within evidence-based practices.

\section{Conclusion.}

Positive human identification through the comparison of CT scans of the frontal sinuses was established. The distinctive morphology of the frontal sinus as result of its shape, size, lobes and

\section{References:}

1. Franco A., Thevissen P., Coudyzer W., Develter W., Van de Voorde W., Oyen R., et al. Feasibility and validation of virtual autopsy for dental identification using the Interpol dental codes. Journal of Forensic and Legal Medicine. 2013; 20 (4): 248-254. Doi: 10.1016/j.jflm.2012.09.021.

2. Angelakopoulos N., Franco A., Willems G., Fieuws S., Thevissen $P$. Clinically detectable dental identifiers observed in intraoral phorographs and extra-oral radiographs validated for human identification purposes. Journal of Forensic Sciences. 2016; 62 (4): 900-906. Doi: 10.1111/1556-4029.13310

3. Senn D.R., Weems R.A. ed. Manual of forensic odontology. 5th ed. Boca Raton: CRC Press; 2013. 461 p.

4. Decker S.J., Braileanu M., Dey C., Lenchik L., Pickup M., Powell J., et al. Forensic radiology: a primer. Acadademic Radiology. 2019; 26 (6): 820-830. Doi: 10.1016/j.acra.2019.03.006.

5. Wood R.E. Forensic aspects of maxillofacial radiology. Forensic Science International. 2006; 159 (1): 47-55. Doi: 10.1016/j.forsciint.2006.02.015.

6. Thali M.J., Viner M.D., Brogdon B.G. ed. Brogdon's forensic radiology. 2nd ed. Boca Raton: CRC Press; 2010. 654 p.

7. Sonnemans L.J.P., Kubat B., Prokop M., Klein W.M. Can virtual autopsy with postmortem CT improve clinical diagnosis of cause of death? A retrospective observational cohort study in a Dutch tertiary referral centre. BMJ Open. 2018; 8 (3): e018834. Doi: 10.1136/bmjopen-2017-018834.

8. Ross S.G., Thali M.J., Bolliger S., Germerott T., Ruder T.D., Flach P.M. Sudden death after chest pain: feasibility of virtual autopsy with postmortem CT angiography and biopsy. Radiology. 2012; 264 (1): 250-259. Doi: 10.1148/radiol.12092415.

9. Ruder T.D., Bauer-Kreutz R., Ampanozi G., Rosskopf A.B., Pilgrim T.M., Weber O.M., et al. Assessment of coronary artery disease by post-mortem cardiac MR. European Journal of Radiology. 2012; 81 (9): 2208-2214. Doi 10.1016/j.ejrad.2011.06.042.

10. Ruder T.D., Thali Y.A., Rashid S.N.A., Mund M.T., Thali M.J., Hatch G.M., et al. Validation of post mortem dental CT for disaster victim identification. Journal of Forensic Radiology and Imaging. 2016; 5: 25-30. Doi: 10.1016/j.jofri.2016.01.006.

11. Furtado G.C., Pompeo D.D., Furtado A., Paranhos L.R., Franco A., Lima-Rivera L.M. Lack of significant volumetric alteration after rapid maxillary expansion supports the use of frontal sinuses for human identification purposes. Journal of Forensic Radiology and Imaging. 2018; 12: 64-67. Doi: 10.1016/j.jofri.2018.02.008.

12. Silva R.F., Rodrigues L.G., Picoli F.F., Bueno J.M., Franco R.P.A.V., Franco A. Morphological analysis of frontal sinuses registered in an occlusal film by intraoral radiographic device A case report. Journal of Forensic Radiology and Imaging. 2019; 17: 1-4. Doi: 10.1016/j.jofri.2019.03.001.

13. Ruder T.D., Brun C., Christensen A.M., Thali M.J., Gascho $D$., Schweitzer W., et al. Comparative radiologic identification septa converged between AM and PM data after qualitative analysis by superimposition - allowing reconciliation between alleged victim and unknown cadaver.

with CT images of paranasal sinuses - Development of a standardized approach. Journal of Forensic Radiology and Imaging. 2016; 7: 1-9. Doi: 10.1016/j.jofri.2016.09.001.

14. Lino M., Fujimoto H., Yoshida M., Matsumoto H., Fujita M.Q. Identification of a jawless skull by superimposing post-mortem and ante-mortem CT. Journal of Forensic Radiology and Imaging. 2016; 6: 31-37. Doi: 10.1016/j.jofri.2015.08.005.

15. Xavier T.A., Terada A.S.S.D., Silva R.H.A. Forensic application of the frontal and maxillary sinuses: a literature review. Journal of Forensic Radiology and Imaging. 2015; 3 (2): 105110. Doi: 10.1016/j.jofri.2015.05.001.

16. Patil N., Karjodkar F.R., Sontakke S., Sansare K., Salvi R. Uniqueness of radiographic patterns of the frontal sinus for personal identification. Imaging Science in Dentistry. 2012; 42 (4): 213-217. Doi: 10.5624/isd.2012.42.4.213.

17. Ribeiro F.A. Standardized measurements of radiographic films of the frontal sinuses: an aid to identifying unknown persons. Ear Nose Throat Journal. 2000; 79 (1): 26-8,30,32-3.

18. Motaweia S.M., Wahba B.A., Aboelmaaty W.M., Tolba E.M. Assessment of frontal sinus dimensions using CBCT to determine sexual dimorphism amongst Egyptian population. Journal of Forensic Radiology and Imaging. 2016; 6: 8-13. Doi: 10.1016/j.jofri.2016.07.001.

19. Chennoju S.K., Ramaswamy P., Khaitan T. Frontal sinus index - a new tool for sex determination. Journal of Forensic Radiology and Imaging. 2014; 2 (2): 77-79. Doi: 10.1016/j.jofri.2014.02.002.

20. Stokovic N., Trkulja V., Cukovic-Bagic I., Lauc T., Grgurevic L. Anatomical variations of the frontal sinus and its relationship with the orbital cavity. Clinical Anatomy 2018; 31 (4): 576-582. Doi: 10.1002/ca.22999.

21. Tatlisumak E., Yilmaz-Ovali G., Aslan A., Asirdizer M., Zeyfeoglu Y., Tarhan S. Identification of unknown bodies by using CT images of frontal sinus. Forensic Science International. 2007; 166 (1): 42-48. Doi: 10.1016/j.forsciint.2006.03.023.

22. Nikam S.S., Gadgil R.M., Bhoosreddy A.R., Shah K.R., Shirsekar V.U. Personal identification in forensic science using uniqueness of radiographic image of frontal sinus. Journal of Forensic Odontoestomatology. 2015; 33 (1): 1-7.

23. Soares C.B.R.B., Almeida M.S.C., Lopes P.M.L., Beltrão R.V., Pontual A.A., Ramos Perez F.M.M. et al. Human identification study by means of frontal sinus imaginological aspects. Forensic Science International. 2016; 262: 183-189. Doi: 10.1016/j.forsciint.2016.03.030.

24. Rabelo K.A., Pontual M.L.A., Jordão N.Q., Paiva K.M., Ramos-Perez F.M.M., Santos M.S. et al. Human identification by FSS system adapted to cephalometric radiographs. Forensic Science International. 2016; 262: 227-232. Doi: 10.1016/j.forsciint.2016.03.025.

25. Silva R.F., Franco A., Dias P.E.M., Gonçalves A.S., Paranhos L.R. Interrelationship between forensic radiology and forensic 


\section{RUSSIAN ELECTRONIC JOURNAL OF RADIOLOGY}

odontology - a case report of identified skeletal remains. Journal of Forensic Radiology and Imaging. 2013; 1 (4): 201-206. Doi: 10.1016/j.jofri.2013.06.005.

26. Silva R.F., Picoli F.F., Botelho T.L., Resende R.G., Franco A. Forensic identification of decomposed human body through comparison between ante-mortem and post-mortem CT images of the frontal sinuses: case report. Acta Stomatologica Croatica. 2017; 51 (3): 227-231. Doi: 10.15644/asc51/3/6.

27. Dedouit F., Savall F., Mokrane F.Z., Rousseau H., Crubézy E., Rougé D., et al. Virtual anthropology and forensic identification using multidetector CT. The British Journal of Radiology. 2014; 87 (1036): 20130468. Doi: 10.1259/bjr.20130468.

28. Dedouit F., Saint-Martin P., Mokrane F.Z., Savall F., Rousseau H., Crubézy E. Virtual anthropology: useful radiological tools for age assessment in clinical forensic medicine and thana- tology. Radiologia Medica. 2015; 120 (9): 874-886. Doi: 10.1007/s11547-015-0525-1.

29. Gietzen T., Brylka R., Achenbach J., Hebel K.Z., Schömer E., Botsch M., Schwanecke U., Schulze R. A method for automatic forensic facial reconstruction based on dense statistics of soft tissue thickness. PLoS ONE. 2019; 14 (1): e0210257. Doi: 10.1371/journal.pone.0210257.

30. Thali M.J., Yen K., Vock P., Ozdoba C., Kneubuehl B.P., Sonnenschein $M$., et al. Image-guided virtual autopsy findings of gunshot victims performed with multi-slice computed tomography (MSCT) and magnetic resonance imaging (MRI) and subsequent correlation between radiology and autopsy findings. Forensic Science International. 2003; 138 (1-3): 8-16. 